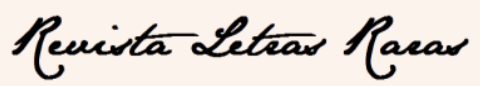

ISSN: $2317-2347$ - v. 8, n. 2 (2019)

\title{
Citação visual: cruzando fronteiras intermidiais em $O$ diário de Anne
}

\section{Frank / Visual citation: crossing intermedial borders in Anne Frank's}

\author{
diary
}

\author{
Ana Luiza Ramazzina Ghirard*
}

\begin{abstract}
RESUMO
A partir da adaptação de $O$ diário de Anne Frank (Folman e Polonsky, 2017), este artigo examina o funcionamento da "citação visual" no ambiente HQ. Analisa-se a presença dessas citações na transposição de uma narrativa textual para uma linguagem multimodal, bem como a inserção e referências midiáticas, subcategoria de intermidialidade proposta por Rajewsky (2012). Segundo Clüver (2011), essa subcategoria apresenta "textos de uma mídia só que citam ou evocam [...] textos específicos ou qualidades genéricas de uma outra mídia.” A proposição de Kristeva (1969) de que todo texto representa uma pluralidade de citações, sendo absorção e transformação de outros textos serve de base para discutir as construções verbal e visual da HQ, mídia que combina dois sistemas semióticos (texto e imagem). A análise da adaptação de Folman e Polonsky, desenvolvida ao longo desse artigo, indica que, ao contrário de um empobrecimento, a reciclagem de mídia transformada em "citação visual" amplia as perspectivas de sua retomada e leitura, cruzando fronteiras e criando interfaces com outras artes.
\end{abstract}

PALAVRAS-CHAVE: HQ; referência intermidial; citação visual; O diário de Anne Frank

\section{ABSTRACT}

Based on the adaptation of a graphic novel version of Anne Frank's diary (by Folman and Polonsky, 2017) this paper examines the functioning of "visual citations" in comics. The presence of such citations is analyzed by examining the transposition of a literary narrative to the multimodal language of comics and the insertion of new media by means of "mediatic references", an intermedial subcategory proposed by Rajewsky (2012). According to Clüver (2011), such subcategory encompasses "texts of a single media which cite or evoke [...] specific texts or qualities of an other media”. Kristeva's assertion (1969) that every text represents a plurality of citations, as it absorbs and transforms other texts, serves as a basis for the discussion of the verbal and visual constructions of the comics, a media which combines two semiotic elements (text and image). The analysis of Folman and Polonsky's adaptation, which is the object of this paper, suggests that, far from being impoverished, the media recycled in "visual citations" get their communicative potential expanded, crossing borders and creating interfaces with other forms of art.

KEYWORDS: Comics; intermedial reference; visual citation; Anne Frank's diary

\section{Introdução}

Dentre as muitas mídias capazes de combinar narrativa textual e imagem, destaca-se a linguagem dos quadrinhos, veículo cuja identidade narrativa caracterizada

\footnotetext{
* Doutora em língua e literatura francesa. Professora Associada da Escola de Filosofia, Letras e Ciência Humanas - UNIFESP, Guarulhos, São Paulo, Brasil. Endereço para contato alramazzina@uol.com.br Todo o conteúdo da Revista Letras Raras está licenciado sob Creative Commons Atribuição 4.0 Internacional
} 


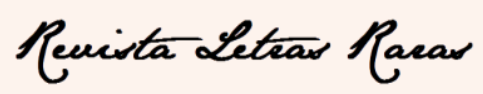

ISSN: $2317-2347$ - v. 8, n. 2 (2019)

pela possibilidade de leitura veloz, oferece um ambiente propício para um jogo de troca de sentidos instantâneo, propiciando o diálogo entre diferentes artes.

Desde Töpffer e sua criação de Monsieur Jabot em 1833, entende-se que os quadrinhos não representam apenas uma sequência de imagens fixas mas se revelam uma mídia cujos diferentes formatos e possibilidades propiciam um campo fértil para a criatividade de seus autores ${ }^{1}$.

Esse artigo destaca uma das possibilidades criativas nos quadrinhos, a Graphic Novel. Eisner é considerado o criador do gênero graphic novels (McCLOUD, 2006, p. 28) e, segundo ele, esse [graphic novel] "é um termo que pode abarcar tanto livros de não ficção como obras genuinamente romanescas" (EISNER, 2015, p. 149). O autor ainda destaca que seus criadores optam por "temas abrangentes e relevantes" e se empenham na "constante inovação em sua abordagem" (2015, p. 149). Eisner indica que

[o] estilo, a apresentação [...], os balões e os quadrinhos ainda são as principais ferramentas do artista sequencial. Sua arte, portanto é a de apresentar imagens e palavras em um equilíbrio proporcionado com maestria, sabendo contornar as limitações formais do meio e criando narrativas ambiciosas que abordem temas atraentes e desafiadores para um público cada vez mais sofisticado e crítico (EISNER, 2015, p. 149).

Além de a Graphic Novel representar um ambiente favorável à adaptação de um texto primeiro em linguagem verbal, ela supera também as narrativas de quadrinhos tradicionais "que não podem mais evitar o confronto com o mundo contemporâneo da globalização e da fusão das linguagens"2 (FIORANI, 2012, p. 189, tradução nossa), ampliando assim a possibilidade do diálogo com outras artes. Segundo Fiorani (2012),

Os quadrinhos hoje são uma mídia que contamina os diversos filões mudando inclusive forma e estatuto, fazendo, com a Graphic Novel $A r t$, da vocação ao romance sua própria bandeira; eles registram a rápida dissolução dos produtos e dos imaginários da invasão japonesa através seja de um quadrinho mais pop e mainstream, seja da nova

\footnotetext{
1 “[...] Töpffer revisou o Jabot e litografou as primeiras cópias em maio de 1833, distribuindo a amigos. [...] ele estava criando [era] de fato uma nova linguagem, na qual imagem se punha em movimento e se integrava perfeitamente ao texto, sem que um fosse mais importante do que o outro" (AUBERT, 2017, p. 11).

2 Texto no original: "che non possono più sottrarsi al confronto con il mondo contemporaneo della globalizzazione e del rimescolamento dei linguaggi” (FIORANI, 2012, p. 189).

Todo o conteúdo da Revista Letras Raras está licenciado sob Creative Commons Atribuição 4.0 Internacional
} 


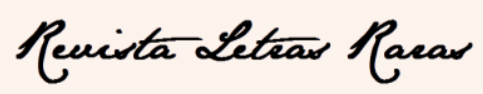

ISSN: $2317-2347$ - v. 8, n. 2 (2019)

sensibilidade dos autores mais intelectuais, inclusive aqueles empenhados na Graphic Novel Art. Por isso, hoje os quadrinhos se apresentam como um fenômeno da globalização cultural, "um mix de línguas que se fundem e continuam a existir; um mercado multiétnico de objetos paradoxalmente standards" (F. Colombo, 2006, p. 11) e um interessante campo de observação das tendências presentes na mídia (FIORANI, 2012, p. 189, tradução nossa). ${ }^{3}$

Fenômeno de globalização cultural, os quadrinhos contemporâneos (que abarcam a Graphic Novel) oferecem um espaço propício para fazer dialogar não apenas diferentes culturas como diferentes mídias, criando uma interlocução entre diversos modos de pensar, de criar, de expressar e de configurar um mesmo objeto. A partir da criatividade de seus autores, um novo produto se define e entra em fricção com artes já existentes, criando um novo universo capaz de alcançar diferentes receptores, favorecendo uma troca de culturas e sistemas midiáticos.

É a partir dessa perspectiva que esse artigo analisa a adaptação para os quadrinhos de O diário de Anne Frank, de Folman e Polonsky (2017), por entender que seus autores ampliam o universo exposto em um diário por uma jovem adolescente em pleno conflito mundial para além de um íntimo desabafo. O cotidiano de Anne Frank, a princípio confinado ao Anexo Secreto, toma novo formato na linguagem dos quadrinhos ampliando as angústias e dúvidas que permeiam o texto escrito. $\mathrm{O}$ novo texto visual oferece ao leitor a combinação de produtos semióticos que criam um espaço de reflexão e combinam diferentes possibilidades intermidiais trazendo à luz uma forma diferente de criar um diálogo com imagens: a citação visual.

O artigo busca oferecer um exemplo concreto da ampliação de sentidos que deriva da combinação de sistemas semióticos, conforme postulado, teoricamente, por Clüver (2011) e Kristeva (1996). Para tanto, contextualizam-se, em um primeiro momento, a obra original (seção 2 - O diário de Anne) e sua adaptação HQ (seção 3 Transposição do diário escrito para a mídia $H Q$ ). Subsequentemente, analisam-se duas instâncias específicas de reconstrução imagética da narrativa (seção 4 - Um feixe de

\footnotetext{
${ }^{3}$ Texto no original: "Il fumetto è oggi un medium che contamina i diversi filoni mutando anche forma e statuto, facendo, con la Graphic Novel Art, della vocazione al romanzo la propria bandiera e registrando la rapida dissoluzione dei prodotti e degli immaginari della japan invasione attraverso sia il fumetto più pop e mainstream sia la nuova sensibilità degli autori più intellettuali, inclusi quelli impegnati nella Graphic Novel Art. Per questo oggi il fumetto si presenta come un fenomeno della globalizzazione culturale, "un mix di lingue che si fondono e continuano ad esistere; un mercato multietnico di oggetti paradossalmente standard" [F. Colombo, 2006: 11] e un interessante campo di osservazione delle tendenze in atto nei media" (FIORANI, 2012, p. 189).

Todo o conteúdo da Revista Letras Raras está licenciado sob Creative Commons Atribuição 4.0 Internacional
} 


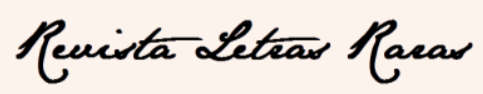

ISSN: $2317-2347$ - v. 8, n. 2 (2019)

contradições) e se oferece uma moldura teórica para a leitura de tal reconstrução (seção 5 - A construção de sentido através de referências midiáticas), enfatizando a importância, dentro dessa moldura teórica, do conceito de citação visual (seção 6 - O que a citação visual revela?). A conclusão sintetiza o percurso argumentativo e retoma a tese central da ampliação de sentidos textuais pela combinação de sistemas semióticos.

A próxima secção apresenta o contexto de produção da obra fonte, assim como as circunstâncias de sua preservação, publicação e circulação, em um processo que a faria uma obra referencial para a cultura do Ocidente e, assim, objeto privilegiado para adaptações.

\section{0 diário de Anne}

Uma das narrativas mais contundentes a respeito da realidade vivida por milhares de famílias judias durante a Segunda Guerra Mundial é construída a partir dos olhos de uma garotinha adolescente em pleno conflito mundial. O diário de Anne Frank até hoje emociona e alerta leitores a respeito das atrocidades vividas por essas famílias em um período em que razões e contradições iluminavam um palco triste da história contemporânea.

Escrito entre 12 de junho de 1942 e $1^{\circ}$ de agosto de 1944, em princípio como registro meramente pessoal, o diário tornou-se um projeto maior para Anne quando a garota ouviu uma transmissão radiofônica em 1944 de um membro do governo holandês no exílio. Gerrit Bolkestein "declarou que depois da guerra, esperava recolher testemunhos oculares do sofrimento do povo holandês sob ocupação alemã e que estes pudessem ser postos à disposição do público" (FRANK; PRESSLER, 2018, p. 7).

A partir desse momento, "impressionada com aquele discurso, Anne Frank decide que publicaria um livro a partir do seu diário" (FRANK; PRESSLER 2018, p. 7) e o transformou em um projeto a ser publicado quando a guerra terminasse. Contudo, seu projeto acaba suspenso e a data $1^{\circ}$ de agosto de 1944 marca o último relato de Anne Frank. Três dias depois, em 4 de agosto de 1944, policiais armados chegam ao anexo secreto em que Anne vivia em Amsterdã, na Holanda, e fazem prisioneiros além dela, 


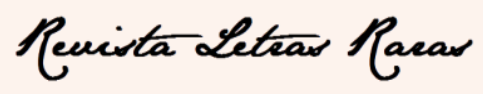

ISSN: $2317-2347$ - v. 8, n. 2 (2019)

seus pais, sua irmã Margot e mais quatros moradores (FRANK; PRESSLER, 2018, p. 349). ${ }^{4}$

Graças a Otto Frank, pai de Anne e único sobrevivente da família, a vontade de Anne e suas inquietações puderam ser conhecidas pelo mundo todo. $\mathrm{O}$ diário, publicado originalmente em linguagem verbal, assume hoje novos formatos (filme, peça de teatro, HQ etc.) que refletem a expansão das novas mídias e contribuem para a difusão de ideias antes confinadas ao público leitor textual, ajudando a replicar o desejo de uma jovem adolescente em transformar suas palavras mais íntimas em uma narrativa que alcançasse pessoas de todas as culturas e religiões.

Em seu último registro, a menina lança uma pergunta: "Por favor, pode me dizer exatamente o que é um feixe de contradições?” (FRANK; PRESSLER, 2018, p. 343). Sua teoria é a de que existam duas definições para a palavra "contradição": a primeira, segundo ela, seria "não aceitar a opinião dos outros, sempre achar que sabe mais, ter a última palavra [...]" (FRANK; PRESSLER, 2018, p. 343); a segunda definição, para Anne, é o seu segredo: ela se vê dividida em duas Annes e confessa que seu "outro lado, um lado melhor e mais bonito" nunca aparece por medo de parecer "ridícula e sentimental" e não ser levada a sério (FRANK; PRESSLER, 2018, p. 344).

O caráter pessoal, íntimo e pungente da narrativa de Anne tornou-se icônico do descompasso entre a delicadeza dos sentimentos humanos e a brutalidade da guerra. A mistura de ingenuidade juvenil e argúcia de observação que fazem a força do Diário fizeram deste um texto central para a compreensão da experiência do século XX. Por força da identificação com a faixa etária da personagem, esse relato apela com força aos jovens. A secção seguinte sugere que a proposta de Folman e Polonsky de transpor o Diário para uma linguagem apreciada por esse público - a HQ - representa, por isso, uma pertinente reatualização midiática desse clássico.

\section{Transposição do diário escrito para a mídia HQ}

\footnotetext{
${ }^{4}$ Anne e sua irmã são levadas para um campo de concentração na Alemanha e morrem, provavelmente, entre fevereiro e março de 1945, em decorrência de uma epidemia de tifo que assolou o inverno daquele ano. É provável que as garotas tenham sido enterradas nas valas comuns de Bergen-Belsen. O campo em que as meninas estavam foi libertado em 12 de abril de 1945 pelas tropas inglesas (FRANK; PRESSLER, 2018, p. 349).

Todo o conteúdo da Revista Letras Raras está licenciado sob Creative Commons Atribuição 4.0 Internacional
} 


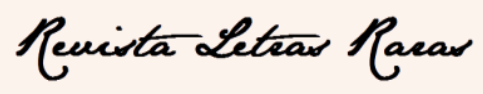

ISSN: $2317-2347$ - v. 8, n. 2 (2019)

O diário de Anne Frank, adaptado para HQ por Ari Folman e David Polonsky (2017, tradução de Raquel Zampil), revela uma outra faceta de seu diário original. Os autores se deparam com a desafiadora tarefa de transformar as palavras escritas em um diário por uma jovem adolescente em uma sequência visual capaz de alcançar crianças e adultos do mundo inteiro (FOLMAN; POLONSKY, 2017, p. 154).

Folman assinala que para honrar "cada letra que Anne escreveu" teria que produzir 3.500 páginas. Sua tarefa, extremamente difícil, era a de selecionar, condensar e ser o mais fiel possível ao texto original (FOLMAN; POLONSKY, 2017, p. 154). A versão $\mathrm{HQ}^{5}$, que este artigo apresenta, testemunha a maestria dos autores ao suprimir e acrescentar elementos e em superar barreiras, indo além de uma simples adaptação do texto original de um diário escrito há mais de sete décadas.

A criatividade de Folman, o roteirista e Polonsky, o ilustrador, ultrapassa os limites impostos pelas sequências fixas de uma HQ e apresenta opções artísticas que cruzam fronteiras intermidiais, acrescentando a esse diário formas lúdicas que constroem a percepção visual das contradições de Anne. Os autores, além de guarnecer a narrativa com as mais diferentes criações imagéticas emocionando o leitor, salpicam ao longo do texto imagens associadas a outras mídias já conhecidas, realizando verdadeiras citações visuais dentro da HQ. Mais que uma sequência de imagens fixas, Folman e Polonsky apresentam uma narrativa multissemiótica ao dispor de diferentes formas de expressão modal que constrói "uma prega do tempo no qual dispositivos sensíveis e dispositivos inteligíveis são contraídos" (MÉCHOULAN, 2012, p. 18-19, tradução nossa) ${ }^{6}$ revelando seu caráter intermidiático.

Logo no início da HQ, é possível perceber a opção artística de seus autores, que combinam diferentes linguagens na forma pela qual apresentam os personagens que participam do diário de Anne (fig. 1). Uma página inteira é dedicada à apresentação que, além dos nomes com suas respectivas imagens, situa, por meio de legendas textuais, todos os personagens em relação à narrativa, com exceção de Anne (por

\footnotetext{
${ }^{5}$ É importante assinalar que ainda que o título original seja Anne Frank: The Graphic Diary, a edição brasileira optou pelo título $O$ diário de Anne Frank (seguindo outras edições: Le jornal d'Anne Frankfrancesa, El diario de Anne Frank - espanhola, Anne Frank - Diario - italiana), não indicando que se trata de uma Graphic Novel. Nesse artigo, HQ será o termo adotado doravante para se referir à obra em questão.

${ }^{6}$ Texto no original : "Penser la situation comme un pli du temps dans lequel dispositifs sensibles et dispositions intelligibles sont contractés est justement ce que l'intermédialité devrait prendre en charge" (MÉCHOULAN, p. 18-19).

Todo o conteúdo da Revista Letras Raras está licenciado sob Creative Commons Atribuição 4.0 Internacional
} 


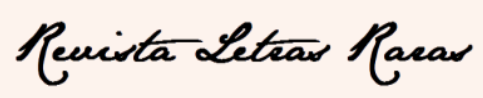

ISSN: $2317-2347$ - v. 8, n. 2 (2019)

exemplo: Margot Frank - irmã de Anne - três anos mais velha). A página funciona como um guia visual: ela está disponível no início da HQ e pode ser consultada a qualquer momento em que o leitor deseje se situar em relação ao personagem.

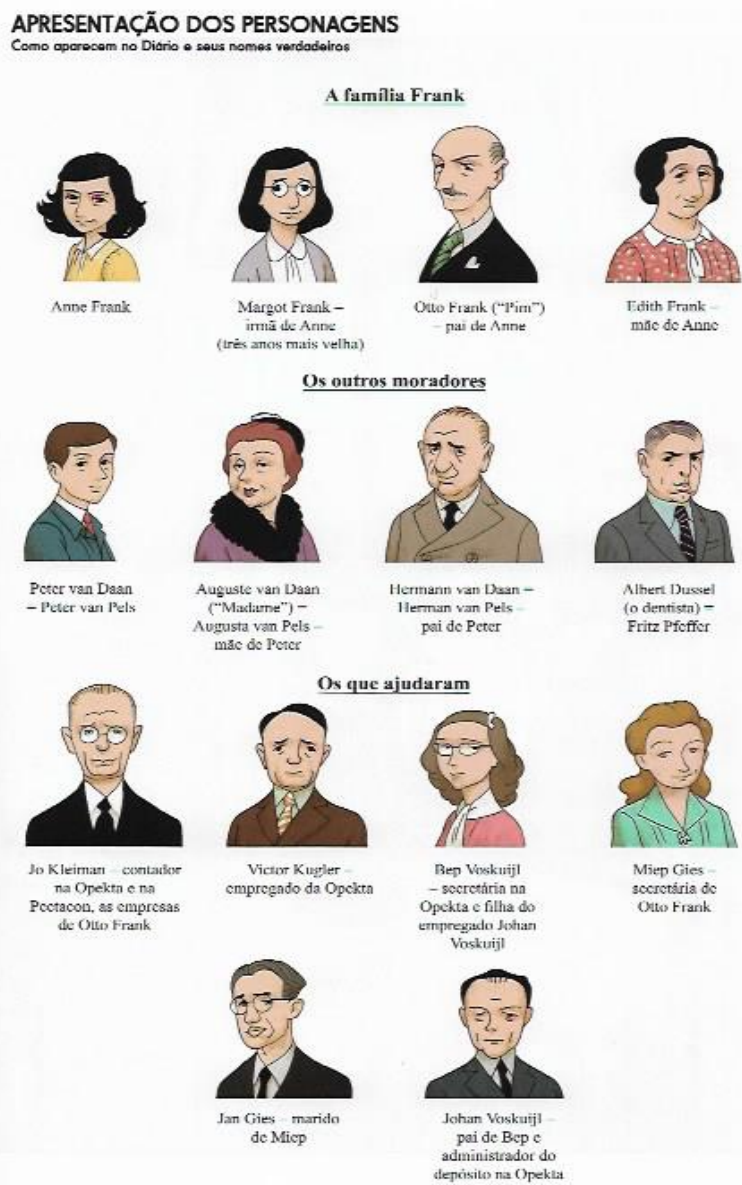

Fig. 1: Apresentação dos personagens (FOLMAN; POLONSKY, 2017, p. 7)

Como abertura da narrativa, os autores optam por antecipar uma informação do diário. Uma vinheta representada por um quadro que ocupa toda a página irá funcionar como introdução, através de uma mensagem visual completa (fig. 2): uma garotinha diante de um bolo com 13 velas acesas e no centro do bolo o número 13. Diante da mesa, há vários pacotes com laços. Ao redor da mesa, veem-se um casal com idade mais avançada, uma garota parecida com Anne e duas garotas bem diferentes. Uma bela cortina emoldura uma grande vidraça e, ao fundo, pode-se ver a cidade com árvores.

\footnotetext{
7 Agradecemos à Anne Frank Fonds (Basel) e a Yves Kugelman (Chefredaktor) pela autorização de reproduzir as ilustrações de $O$ diário de Anne Frank (2017).

Todo o conteúdo da Revista Letras Raras está licenciado sob Creative Commons Atribuição 4.0 Internacional
} 


\section{Reuista Leteas Racar}

ISSN: 2317-2347 - v. 8, n. 2 (2019)

Não há dúvidas, mesmo que não haja linguagem textual, que o desenho marca a festa de aniversário de 13 anos de Anne em um apartamento elegante e, de acordo com o guia visual, sabe-se que a seu lado estão seus pais, sua irmã Margot e duas garotas que serão identificadas três quadrinhos depois: Hanneli e Jacque (segundo Anne, talvez suas melhores amigas).

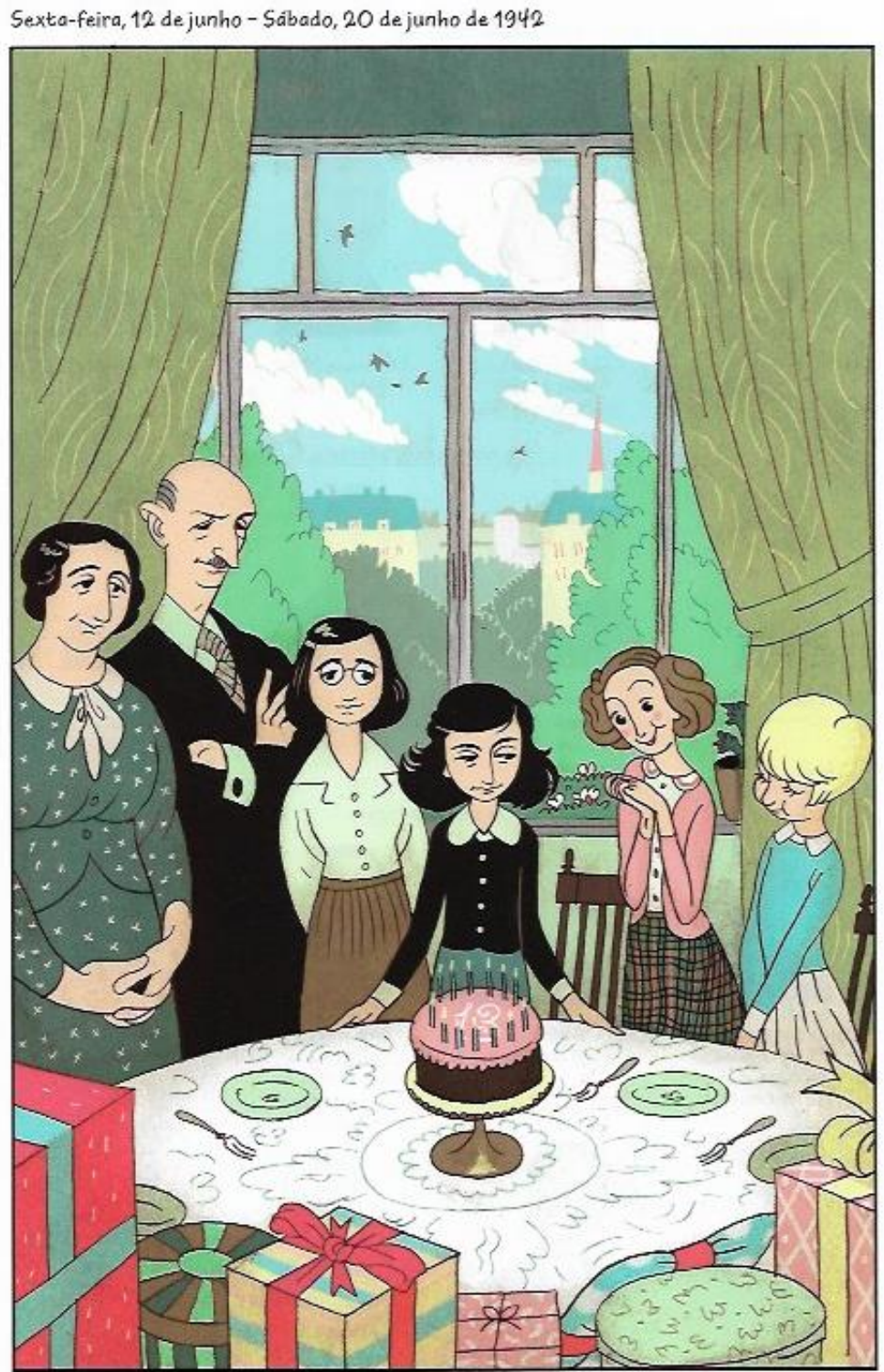

1. 8$)$

8

Após duas páginas de uma narrativa HQ com formato mais tradicional e conhecido do público leitor dessa mídia (uma sequência de quadrinhos com legendas marcando a narrativa de Anne), uma imagem, agora sem moldura, toma toda a página (fig. 3). Nela, vê-se Anne cochichando ao ouvido de Kitty, seu diário, representado por

Todo o conteúdo da Revista Letras Raras está licenciado sob Creative Commons Atribuição 4.0 Internacional 


\section{Reuista Leteas Paear}

ISSN: 2317-2347 - v. 8, n. 2 (2019)

uma silhueta feminina negra saindo de dentro das páginas de um diário e a frase: "Querida Kitty, espero poder contar tudo a você, como nunca pude contar nada a ninguém, e espero que você seja uma grande fonte de conforto e ajuda" (FOLMAN; POLONSKY, 2017, p. 11).

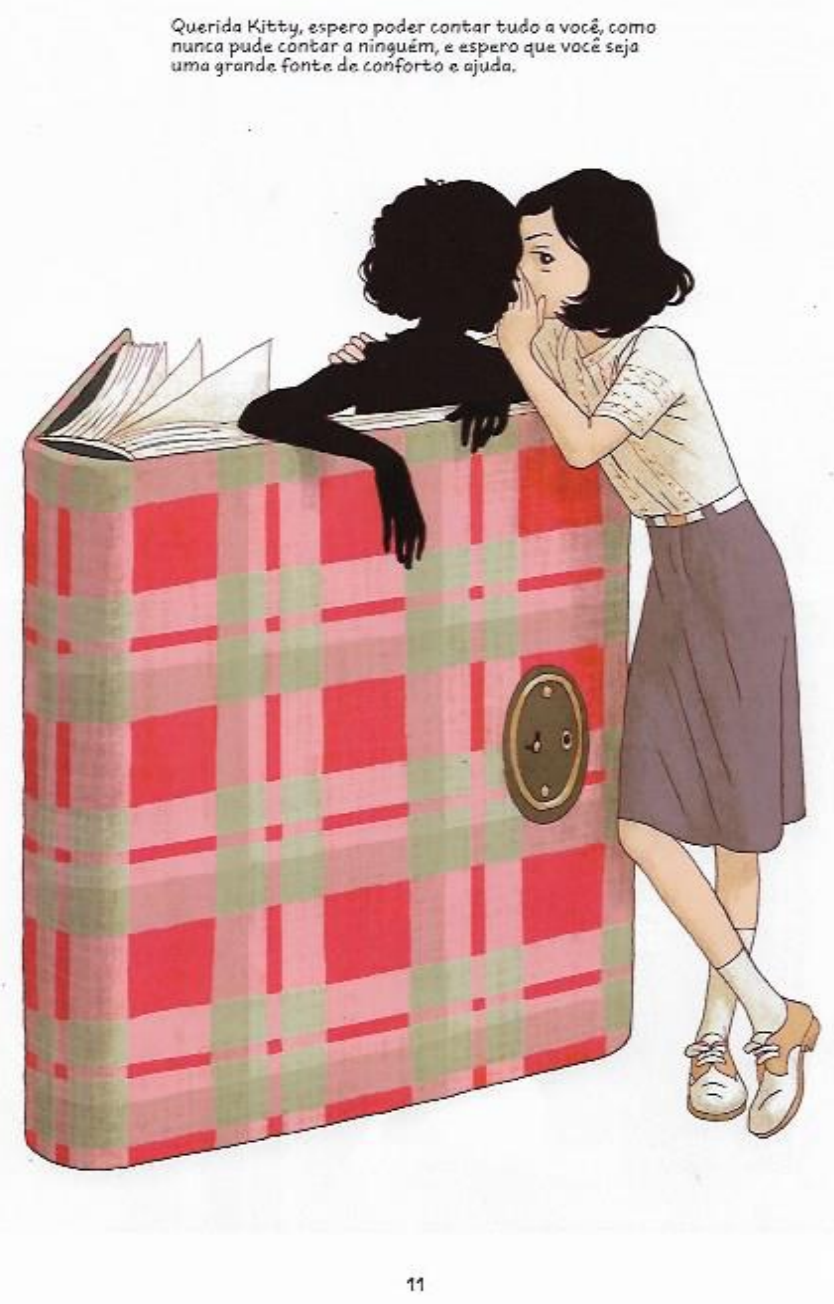

Fig. 3: Anne cochichando ao seu diário (FOLMAN; POLONSKY, 2017, p. 11)

A frase que abre o texto original do diário de Anne em 12 de junho de 1942 é reproduzida ("espero poder contar tudo a você...") e a expressão "querida Kitty" é acrescentada. Esse acréscimo conjugado à imagem oferece ao leitor a ideia da relação íntima que Anne cria com seu diário como se fosse de fato uma amiga a quem faz confidências.

Todo o conteúdo da Revista Letras Raras está licenciado sob Creative Commons Atribuição 4.0 Internacional 


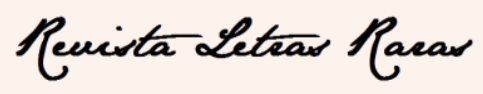

ISSN: $2317-2347$ - v. 8, n. 2 (2019)

A maestria com que Folman e Polonsky adaptam o diário de Anne em HQ pode ser verificada em muitas passagens ao longo dessa criação, que representa um denso multitexto e transforma essa nova mídia em uma verdadeira testemunha de variações semióticas. Os exemplos destacados acima se revelam importantes porque permitem a discussão do tema eleito para análise nesse artigo: a relação entre diferentes produtos semióticos nos quadrinhos e como eles constroem um novo universo que ajuda o leitor contemporâneo a construir, a partir de suas expectativas e repertório, o universo de Anne no Anexo Secreto.

Nesse processo, importa examinar mais de perto uma passagem particularmente significativa do caleidoscópio de linguagens realizado pelos autores, uma vez que ela, além de incorporar outra linguagem semiótica, busca na intermidialidade sua fonte referencial. Trata-se da cena do desabafo de Anne sobre suas contradições: um jogo de textos e imagens é introduzido na narrativa, criando citações visuais que orientam o leitor para a compreensão dos sentimentos da jovem adolescente.

A complexidade da experiência de Anne, em que o sentido dos eventos (e de sua própria vida) nunca está na superfície, mas precisa ser buscado incessantemente sob as aparências - faz com que ela se sinta frequentemente em descompasso consigo mesma, incapaz de estabelecer uma moldura mais ampla para situar suas emoções.

A secção seguinte sugere que, na obra de Folman e Polonsky, a citação visual cumprirá a função de estabelecer uma ligação entre a singularidade de Anne e o sentido geral de sua experiência: não apenas a menina, mas toda a cultura ocidental (representada pelas obras consagradas de Munch e Klint) era, naquele momento, "um feixe de contradições".

\section{Um feixe de contradições}

Em seu relato de 30 de janeiro de 1943, Anne revela a seu diário Kitty suas contradições mais profundas. Anne confessa estar "explodindo de raiva". Seu alvo mais agudo é a mãe, que ela acusa de lhe dirigir "palavras horríveis", "olhares de ironia" e "acusações" que a "furam como flechas". Anne se encontra em um momento de dúvidas e feridas que, segundo ela, são causadas não apenas por sua mãe, mas também por sua 


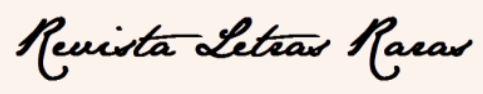

ISSN: $2317-2347$ - v. 8, n. 2 (2019)

irmã Margot, seu pai, os van Daan e Dussel (moradores do Anexo). Ela sente "vontade de gritar" (FRANK; PRESSLER, 2018, p. 92).

O feixe ao qual ela se refere (em seu último relato de $1^{\circ}$ de agosto de 1944) já pode ser notado aqui e desemboca em contradições explicitas: por exemplo, quando ela fala, acusam-na de querer aparecer; ela é ridícula quando se cala; insolente quando responde, preguiçosa quando está cansada, egoísta quando come a mais do que deveria, imbecil, covarde, calculista e, segundo ela, outros tantos adjetivos (FRANK; PRESSLER, 2018, p. 92). Segundo a garota, ela se encontra em um momento em que gostaria de ter "outra personalidade, uma que não criasse antagonismos com todo mundo" (FRANK; PRESSLER, 2018, p. 92).

Anne confessa a Kitty: "preferiria o meio-termo de ouro, que não é tão dourado assim, e guardar para mim meus pensamentos" (FRANK; PRESSLER, 2018, p. 93). E termina seu relato com as palavras "Ah, se eu pudesse!" (FRANK; PRESSLER, 2018, p. 93). Esse desabafo encerra o seu relato do dia 30 de janeiro de 1943.

$\mathrm{Na} \mathrm{HQ}$, a página 59 reproduz o texto de Anne quase na sua íntegra (fig. 4) e acrescenta à linguagem textual uma imagem de mãe e filha em uma discussão, com falas adicionais introduzidas pelo autor da HQ que ilustram o momento de tensão entre elas: "Por que simplesmente não desiste de mim? Sou um caso perdido./Nunca mais fale assim comigo./Que importância isso tem? Você vai me ignorar por uma semana mesmo" (FOLMAN; POLONSKY, 2017, p. 59). 


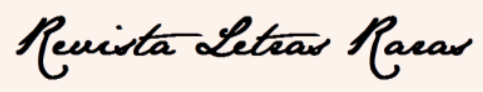

ISSN: $2317-2347$ - v. 8, n. 2 (2019)

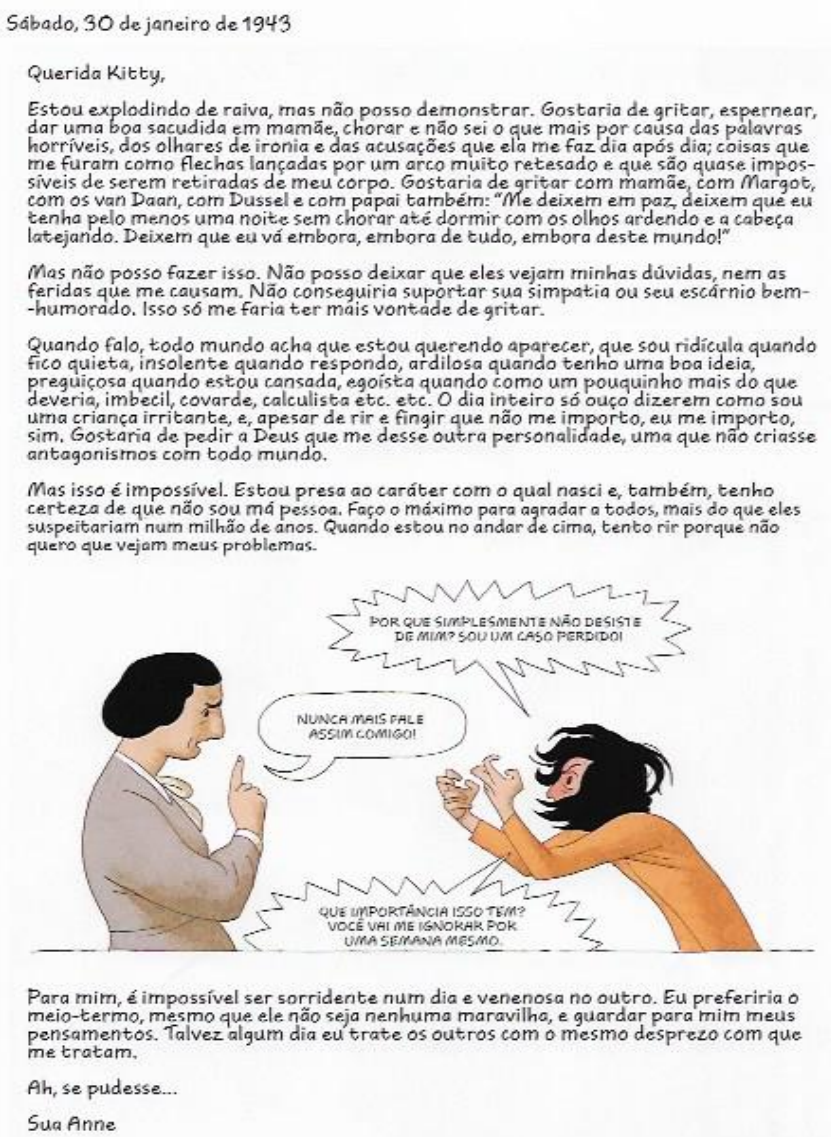

59

Fig. 4: Sábado, 30 de janeiro de 1943 (FOLMAN; POLONSKY, 2017, p. 59)

Além desse acréscimo, o ponto de exclamação do texto original - que encerra o relato no texto de Anne - é substituído na HQ por pontos de suspensão (fig. 4). Em um primeiro momento, essa troca de pontuação pode parecer inocente e sem nenhum objetivo; contudo, o leitor mais atento saberá que ela produz o efeito de deixar a página aberta para introduzir a sequência de ilustrações que completarão a mensagem textual da narrativa.

Segundo Baetens (2009), o que vai dar ritmo e diferenciar as unidades do livro é a página. "A unidade da página é utilizada de modo quase didático: virar a página (ou a 


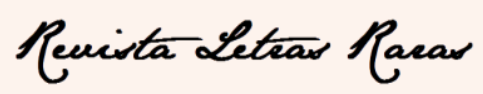

ISSN: $2317-2347$ - v. 8, n. 2 (2019)

página dupla) significa mudar de tema e de estilo. [...] O leitor é convidado a descobrir um fio narrativo religando elementos não contíguos [...]" $\left(2009\right.$, p. 89 , tradução nossa). ${ }^{8}$

$\mathrm{Na} \mathrm{HQ}$, ao virar a página, o leitor se surpreende com a retomada do tema "contradições" (tema recorrente ao longo do diário de Anne) em uma página dupla com duas imagens que evocam outra mídia e retomam as angústias de Anne indicadas por vários balões de fala criando um ambiente propício para o diálogo com uma citação de outro texto, aqui visual. Segundo Compagnon,

[...] a citação é um lugar de acomodação previamente situado no texto. Ela o integra em um conjunto ou em uma rede de textos, em uma tipologia das competências requeridas para a leitura; ela é reconhecida e não compreendida, ou reconhecida antes de ser compreendida (COMPAGNON, 1996, p. 22).

Para retomar as angústias de Anne, no trabalho de Folman e Polonsky a citação cria uma rede de textos que devem ser lidos em um único conjunto. Abaixo, na página da esquerda (Fig. 5), pode-se ver Anne assustada, com as mãos no rosto e as frases:

Por que você precisa chamar atenção o tempo todo? / Você não pode nos dar uma ajuda na cozinha? / A melhor coisa para você seria rezar. / Pelo amor de Deus, Anne, não consigo dormir!/ Margot jamais faria isso! / Não entre em pânico. É só um bombardeio... / Por que você não pode ser como sua irmã? / Pense em quanta sorte você tem! Há crianças morrendo lá fora (FOLMAN; POLONSKY, 2017, p. 60).

Na página da direita, por outro lado, Anne está vestida suntuosamente e os balões dizem: "Cabelo: bem escovado / Olhos: abertos, sorridentes / Nariz: voltado para baixo, sem nenhum toque de esnobismo / Boca e lábios: sorriso constante / Postura: magnífica. Digna e elegante / Vestido: cores vivas, mostrando o otimismo" (Fig. 6, FOLMAN; POLONSKY, 2017, p. 61). Esse contraste construído a partir de citações visuais é repleto de implicações: ele estabelece uma dinâmica narrativa que espelha o jogo de singular/universal que é uma das forças do Diário, como se verá a seguir.

\footnotetext{
${ }^{8}$ Texto no original : L'unité de la page est utilisée de façon quasi didactique: tourner la page (ou la double page) signifie changer de sujet et de style. [...]Le lecteur est invité à découvrir un fil narratif en reliant des éléments non contigus [...] (BAETENS, 2009, p. 89).

Todo o conteúdo da Revista Letras Raras está licenciado sob Creative Commons Atribuição 4.0 Internacional
} 


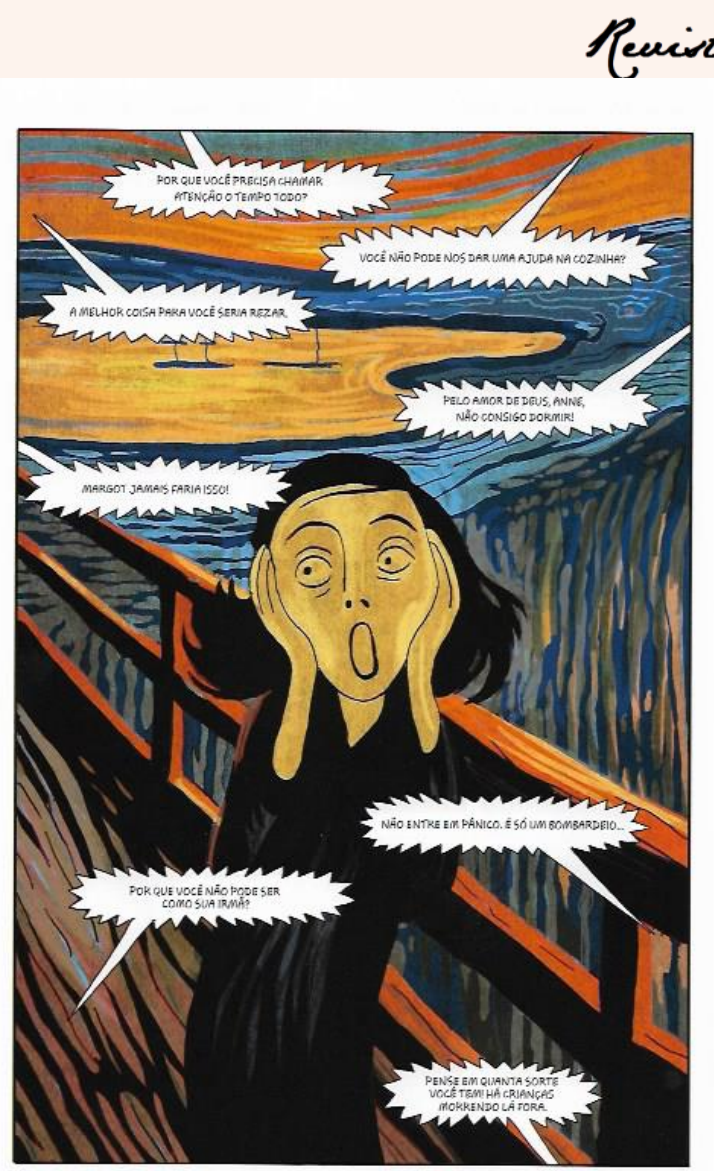

60
$-2347$

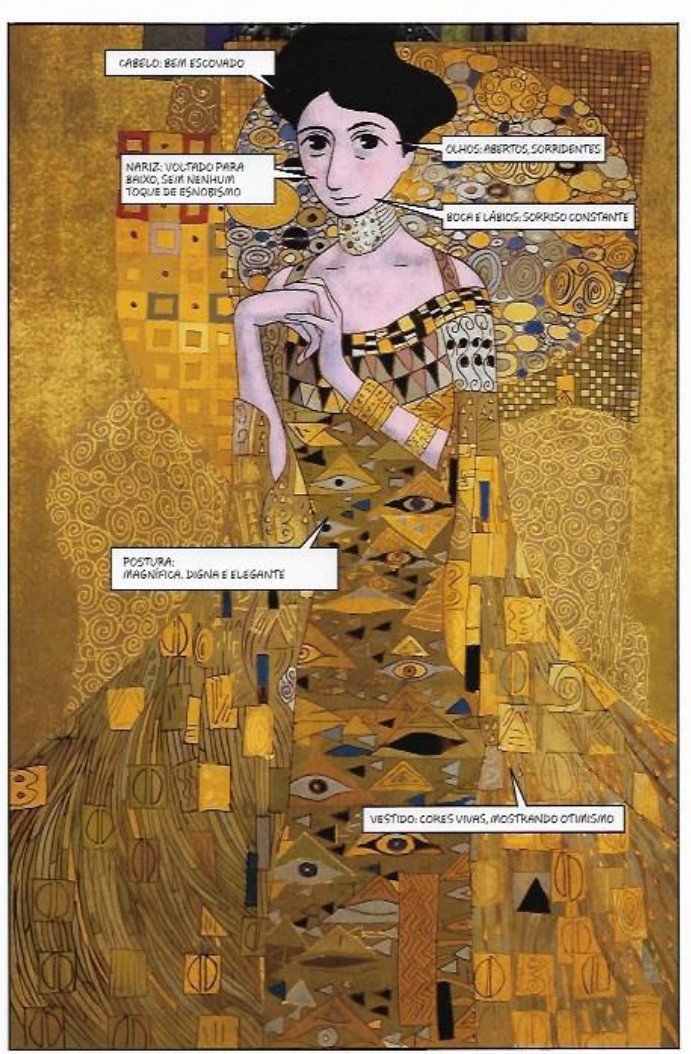

Figuras 5 e 6: página dupla da HQ (FOLMAN; POLONSKY, 2017, p. 60-61)

\section{A construção de sentido através de referências midiáticas}

Essa sequência de página dupla com duas vinhetas que ocupam toda a página, complementam as palavras escritas por Anne em seu diário. Além de misturar linguagem verbal e visual, o conjunto de imagens introduz um apelo citacional causado pelas ilustrações em uma criação multimodal e introduzem uma subcategoria de intermidialidade definida por Rajewsky (2012, p. 25) como "referências midiáticas". Segundo a autora as referências midiáticas

[...] devem ser compreendidas como estratégias de constituição de sentido que contribuem para a significação total do produto: este usa seus próprios meios, seja para se referir a uma obra individual específica produzida por outra mídia [...], seja para se referir a um subsistema midiático específico (como um determinado gênero de filme), ou a outra mídia como sistema [...]. Esse produto, então, se constitui parcial ou totalmente em relação à obra, sistema ou 


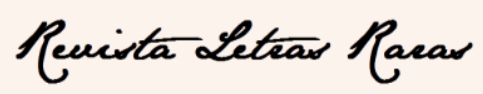

ISSN: $2317-2347$ - v. 8, n. 2 (2019)

subsistema a que se refere. [...] neste caso, por definição, é apenas uma mídia que está em sua própria materialidade - a mídia de referência (em oposição à mídia a que se refere). [...] esse produto de mídia tematiza, evoca ou imita elementos ou estruturas de outra mídia, que é convencionalmente percebida como distinta, através do uso de seus próprios meios específicos (RAJEWSKY, 2012, p. 25-26, grifos no original).

Aqui a mídia de referência, que está em sua materialidade, é a HQ. As imagens introduzidas nessas duas vinhetas evocam outra mídia e representam a mídia a que se refere a HQ: a pintura. Com grande habilidade, o quadrinista busca no ambiente da mídia HQ a referência a duas obras individuais específicas produzidas em outra mídia: "O grito" (1893) de Edvard Munch e "O retrato de Adele-Bauer" (1907) de Gustav Klint. Há a expectativa de que as pinturas possam ser reconhecidas graças ao conhecimento enciclopédico do receptor.

Conforme indica Clüver (2006, p. 27), “as mídias palavra e imagem estão intrinsecamente fundidas" e, desse modo, existem

[p]ossibilidades de transportar um texto intermídias para outras mídias e conduz[ir] o outro texto que pode ser compreendido apenas como uma citação desse exemplo, para com isso, obter um efeito intertextual através da intermidialidade (CLÜVER, 2006, p. 18).

Neste caso, as imagens transportadas indicam uma citação que não apresenta uma relação com o real, mas sim uma relação intertextual criada a partir de duas obras citadas. Para que ela seja compreendida, é necessário que sua interpretação remeta à compreensão do fato de que ela é citação, isto é, reinscrição de uma obra anterior.

Esse tipo de recurso tem na expressão "citação visual" sua definição. MarieFrance Chambat-Houillon, especialista em citação visual em emissões televisivas, aponta a "incapacidade em literatura de citar literalmente todo tipo de imagens (quadro, gravura, fotografia)" 9 e para contornar esse obstáculo imposto pelo texto escrito, [a literatura] vai buscar "intermédio da transemiotização dos signos icônicos em signos linguísticos, únicos signos aceitáveis e compatíveis com o lugar final de integração: o

\footnotetext{
${ }^{9}$ Texto no original : «l'incapacité en littérature de citer littéralement toutes les sortes d'images (tableau, gravure, photographie) » (CHAMAT-HOUILLON, 2010, p. 2).

Todo o conteúdo da Revista Letras Raras está licenciado sob Creative Commons Atribuição 4.0 Internacional
} 


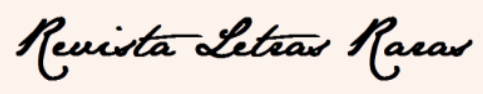

ISSN: $2317-2347$ - v. 8, n. 2 (2019)

texto escrito"10 (CHAMBAT-HOUILLON, 2010, p. 2). No espaço televisivo, entretanto, pela natureza plurissemiótica de sua linguagem, a citação visual se torna possível - por causa dos recursos disponíveis - mas, ao mesmo tempo, e por esta mesma razão, torna-se menos perceptível ao espectador porque está envolta em um conjunto mais amplo de signos cujo "princípio de hierarquização é menos explicito e coercitivo" do que em um texto escrito (CHAMBAT-HOUILLON, 2010, pp. 2-4). ${ }^{11}$

A possibilidade de citação visual desenvolvida por Chambat-Houillon é transportada nesse artigo para o interior da mídia HQ. Em O diário de Anne Frank, a evocação dos quadros só pode ser percebida como uma citação visual se o receptor identificar algumas características próprias das duas pinturas como, por exemplo, a postura das mãos e a expressão de medo ressaltada pelo formato da boca e dos olhos do quadro de Munch, e a postura corporal de Adele, bem como o dourado de sua vestimenta, retratado por Klint.

Compagnon (2016) ${ }^{12}$, em La seconde main ou le travail de la citation, observa que

A citação tem o status de um critério de validação, de um controle de enunciação, de um dispositivo de regulação, às vezes de autorregulação, da repetição do já dito: "boa", ela qualifica; "ruim", ela desqualifica. Longe de ser um detalhe do livro, um traço periférico da leitura e da escritura, a citação representa um desafio capital, um lugar estratégico e até político, em toda prática de linguagem, quando ela assegura sua validação, garante sua aceitação, ou ao contrário as refuta (COMPAGNON, 2016, p. 12-13, tradução nossa). ${ }^{13}$

Ao recorrer às imagens dos quadros e inseri-las no texto HQ, Folman e Polonsky criam um diálogo entre o objeto citado, o texto citante e o leitor-receptor da HQ. Ainda segundo Compagnon (2016), "o terceiro detém a verdade da citação que é o

10 Texto no original: «le truchement de la transsémiotisation des signes iconiques en signes linguistiques, seuls signes acceptables et compatibles avec le lieu final d'intégration : le texte écrit » (CHAMAT-HOUILLON, 2010, p. 2).

${ }^{11}$ Texto no original: « et dont le principe de hiérarchisation est beaucoup moins explicite et coercitif dans une émission que dans un livre ou un article de journal » (Chambat-Houillon, 2010, pp. 2-4).

12 As citações de Compagnon indicadas pelo ano de 2016 que não se encontram na versão traduzida para português pela editora UFMG (2007) serão traduzidas por nós.

${ }^{13}$ Texto no original : «La citation a le statut d'un critère de validité, d'un contrôle d'énonciation, d'un dispositif de régulation, parfois d'autorégulation, de la répétition du déjà dit : «bonne », elle qualifie ; «mauvaise », elle disqualifie. Loin d'être un détail du livre, un trait périphérique de la lecture et de l'écriture, la citation représente un enjeu capital, un lieu stratégique et même politique, dans toute pratique du langage, quand elle assure sa validité, garantit sa recevabilité, ou au contraire les réfute » (COMPAGNON, 2016, p. 12-13).

Todo o conteúdo da Revista Letras Raras está licenciado sob Creative Commons Atribuição 4.0 Internacional 


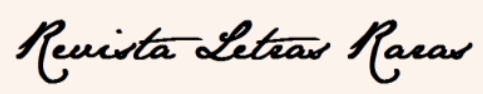

ISSN: $2317-2347$ - v. 8, n. 2 (2019)

julgamento"14 (idem, p. 88, tradução nossa)". O terceiro aqui, o receptor, fará sua apreciação sobre a imagem e a citação só surtirá o efeito desejado se ele for capaz de compreendê-la e acrescentá-la ao universo explorado no texto citante que o apresenta.

Esse artifício usado pelos autores da HQ se torna possível, pois o sistema multitextual da narrativa está aberto para receber diversas possibilidades semióticas. Segundo Groensteen (2015), por suas particularidades morfossintáticas, a HQ é um lugar privilegiado para acolher citações pois "combina dois sistemas semióticos diferentes, o texto e a imagem"15 (GROENSTEEN, 2015, p. 145). Soma-se a isto "o caráter descontinuo de seu discurso" o que faz "dessa mídia um lugar de acolhimento privilegiado para todas as citações, o veículo ideal de uma estética de colagem e de empréstimo" (GROENSTEEN, 2015, p. 145). ${ }^{16}$

O autor ainda sublinha que esta técnica é utilizada pelos autores de HQ para tomar o leitor como testemunha, "torná-lo cúmplice do prazer que experimenta em se deslocar em um campo de referências culturais, na Enciclopédia de seu tempo e de seu meio" ${ }^{17}$ (GROENSTEEN, 2015, p. 144 - grifo no original). Groensteen ainda destaca que

[e]ssas referências funcionam como uma rede [...], as mais implícitas dentre elas só são detectadas porque o contexto despertou nossa vigilância [...] e a orientou em determinada direção [...]. Convidado a se transformar em um verdadeiro detetive, o leitor não sabe onde terminará sua investigação ${ }^{18}$ (GROENSTEEN, 2015, p. 144-145).

Essa cumplicidade demanda do leitor uma postura ativa, uma permanente releitura de seus repertórios de referências internas que, como se discute na próxima secção, amplia a polissemia narrativa da versão HQ.

\footnotetext{
${ }^{14}$ Texto no original : « le tiers détient la vérité de la citation, qui est le jugement » (idem, p. 88).

15 Texto no original: «elle combine deux systèmes sémiotiques différents, le texte et l'image (GROENSTEEN, 2015, p. 145).

${ }^{16}$ Texto no original : «de ce médium un lieu d'accueil privilégié pour toutes les citations, le véhicule idéal d'une esthétique du collage et de l'emprunt »(GROENSTEEN, 2015, p. 145).

${ }^{17}$ Texto no original: «de le rendre complice du plaisir qu'il éprouve à s'ébrouer dans un champ de références culturelles, dans l'Encyclopédie de son temps et de son milieu »(GROENSTEEN, 2015, p. 145).

${ }^{18}$ Texto no original: «[c]es références fonctionnent sur le mode du réseau [...] les plus implicites d'entre elles ne sont détectables que parce que le contexte a éveillé notre vigilance [...] et l'a orientée dans des directions données [...]. Invité à se transformer en véritable détective, le lecteur ne sait où s'arrêtera sa traque » (GROENSTEEN, 2015, p. 144-145).

Todo o conteúdo da Revista Letras Raras está licenciado sob Creative Commons Atribuição 4.0 Internacional
} 


\section{Reuista Leteas Racas}

ISSN: $2317-2347$ - v. 8, n. 2 (2019)

\section{0 que a citação visual revela?}

Quais as possibilidades abertas pela citação visual de Folman e Polonsky? Segundo Compagnon (1979), a citação representa "em si mesma uma força e um deslocamento" pois "é o espaço privilegiado do trabalho do texto; ela lança, ela relança a dinâmica do sentido e do fenômeno" (COMPAGNON, 1996, p. 58). Nessa HQ, as angústias e contradições vividas por Anne são lançadas e relançadas por meio de uma fricção com o sentido das pinturas e a relação intermidiática que provocam.

$\mathrm{Na}$ referência ao quadro de Munch, em um primeiro momento, é possível associar as contradições de Anne à sua vontade de gritar (que ela repete três vezes em seu diário) com todos que a cercam, em um mundo que ela tem vontade de deixar (fig. 7).
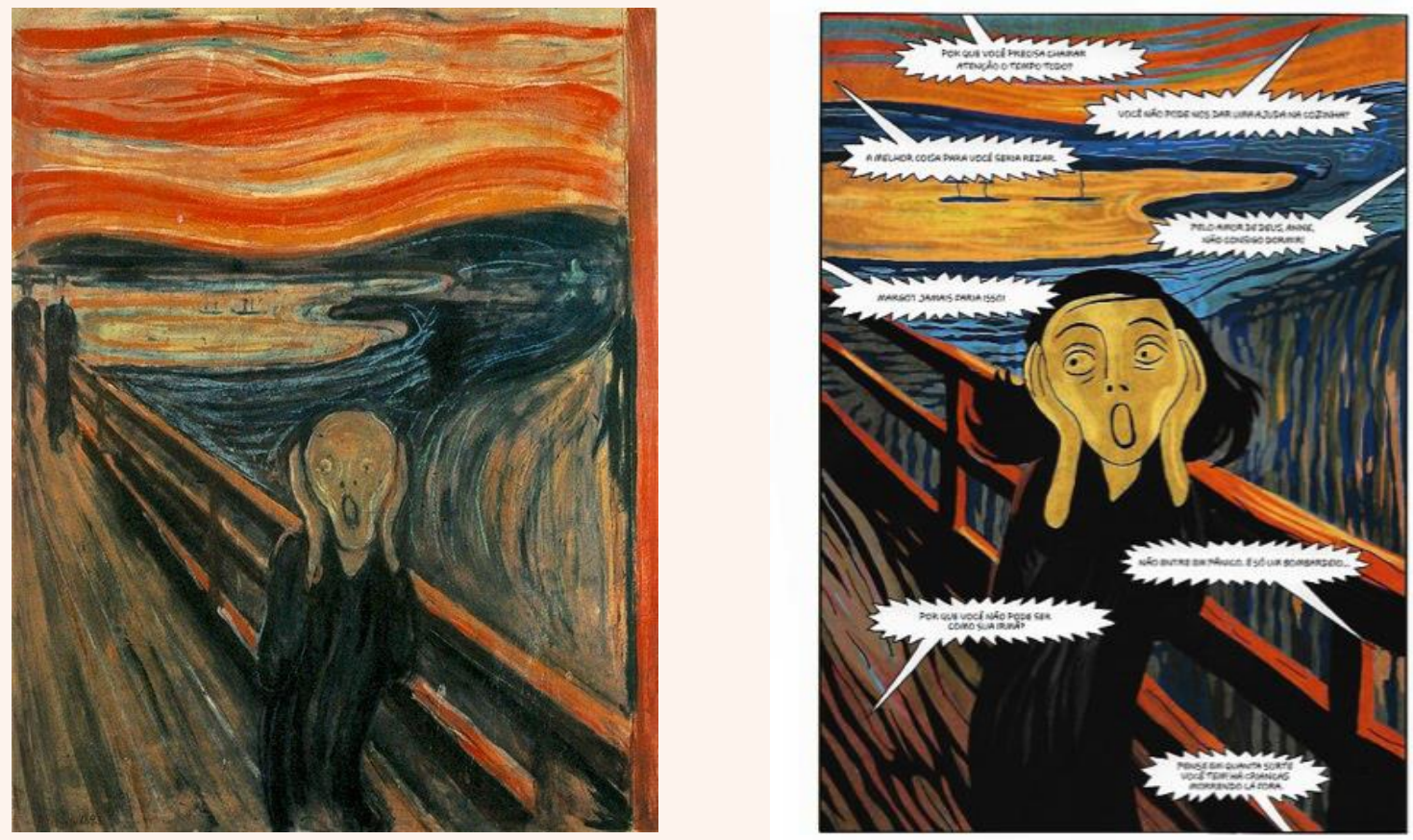

60

Fig. 7: O grito (Edvard Munch, 1893) e vinheta Anne Frank p. 60

"O grito", citado visualmente na página 60 da HQ, mostra o rosto de Anne substituindo a figura distorcida criada por Munch, enquanto frases em balões retomam suas incertezas confessadas a Kitty. Segundo Cagnin (2014), 


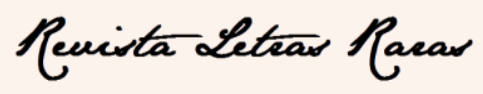

ISSN: $2317-2347$ - v. 8, n. 2 (2019)

Enquanto invólucro da fala, o balão também tornou-se imagem para representar as diversas reações e emoções por que passa a personagem, formas metalinguísticas portanto, como a entonação da voz, o medo, o gaguejar, a raiva entre outros [...] (CAGNIN, 2014, p. 141).

Os balões nessa página têm a forma que Cagnin (2014) denomina "balão-grito" (ou balão-berro) que, segundo o autor, "tem as extremidades dos arcos voltadas para fora, como explosão" (CAGNIN, 2014, p. 142). Os apêndices deixam claro que as vozes vêm do exterior e não de Anne, pois estão direcionadas para todos os lados externos da vinheta.

A citação pode ser imediatamente visível nesta obra HQ que a acolhe, já que os múltiplos índices dessa citação permitem seu reconhecimento. Há uma reciclagem clara de mídia: a pintura se revela como uma vinheta no interior da HQ. Os índices estão aparentes para mostrar que há um empréstimo, um deslocamento, uma retomada; eles remetem claramente a uma citação visual, uma intenção intertextual. A função da citação nesse estado privilegia o sentido do que é citado, a carga de sentido que carrega a pintura de Munch.

A retomada desse quadro, expoente da pintura expressionista, mostra "a emoção por meio da distorção de formas e cor", é fiel à vontade de seu autor em "pintar emoções extremas" (STRICLAND; BOSWELL, 1992, p. 123). Segundo Strickland \& Boswell (1992), nesse quadro, o autor "representa o medo intolerável de perder a razão, [...] cada linha oscila, se agita, trazendo ritmos turbulentos, sem sossego para o olho [...].” Nas palavras de Munch, "[a]cima do fiorde azul-negro, pairam nuvens vermelhas como sangue, vermelhas como línguas de fogo" (STRICLAND; BOSWELL, 1992, p. 123).

A paisagem distorcida com nuvens "vermelhas como sangue" evocam o mundo de guerra e o Anexo Secreto em que vive Anne. As línguas de fogo podem facilmente ser associadas às palavras difíceis lançadas pela mãe de Anne. A garota tem vontade de gritar e deixar esse mundo se entregando a um silêncio ensaiado pelas mãos que cobrem os ouvidos e que recusam o grande ruído que a circunda. Barbieri acredita que "os grandes ruídos são espetaculares” (BARBIERI, 2017, p. 151). Segundo o autor,

São a voz que grita, o estrondo de uma pancada, o impacto de uma palmada... todos eventos de breve duração e de grande intensidade. 


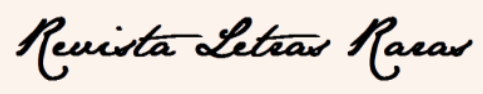

ISSN: 2317-2347 - v. 8, n. 2 (2019)

Assim como em nossa vida um estrondo marca um momento intenso, talvez de perigo, mas em qualquer caso, de emoção - mesmo que seja apenas de incômodo -, também quando os grandes ruídos aparecem nos quadrinhos ocupam um espaço fundamental como posição ou como dimensão, ou como ambas as coisas (BARBIERI, 2017, p. 151).

Já “O retrato de Adele-Bauer”, citado visualmente na página 61 da HQ (fig. 8), apresenta o rosto de Anne substituindo Adele-Bauer e balões com os apêndices voltados para a sua boca, índice de que nessa vinheta, ao contrário da anterior, é "a voz de Anne" que fala sobre sua aparência. Dessa vez, os balões tomam outra forma, são o "balãofala, o mais comum, tem seu contorno nítido, contínuo" (CAGNIN, 2014, p. 141). Ainda que esse balões deixem claro que são palavras de Anne, o formato retangular lembra as legendas que introduzem o narrador na HQ. Cagnin (2014) observa que a legenda em uma HQ, “é um pequeno fragmento do discurso, sem outro objetivo senão o de fixação de um significado (a ancrage de Barthes)" (CAGNIN, 2014, p. 141).

Pode-se pensar que os balões com formatos mais parecidos com espaços para legendas tenham aqui sido usados para fixar a mensagem da imagem à aparência de Anne e, como se além da voz de Anne, uma segunda voz se sobrepusesse e ditasse conselhos que a garota deveria seguir.
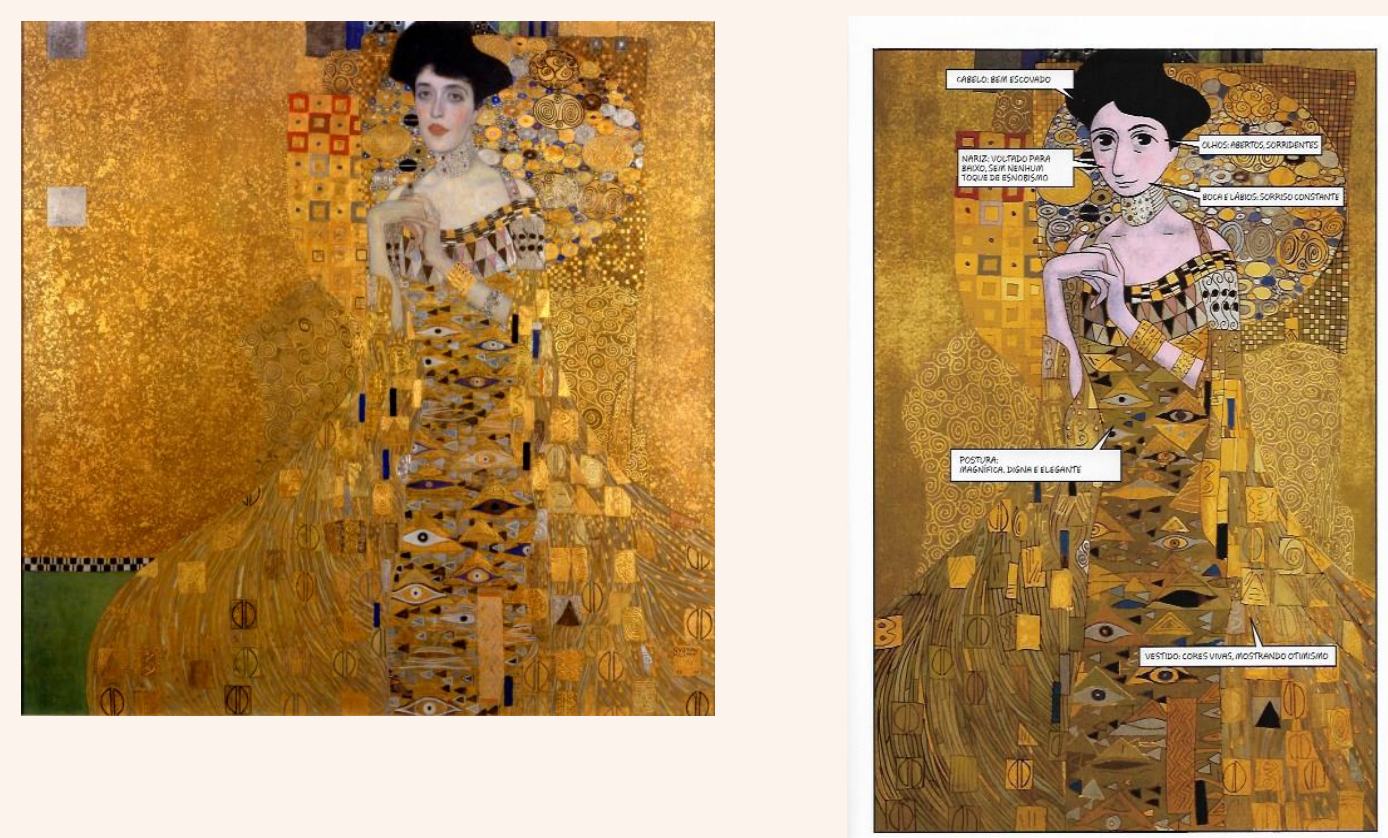

61

Fig. 8: O retrato de Adele-Bauer (G. Klint, 1907) e vinheta de Anne Frank, p. 61 


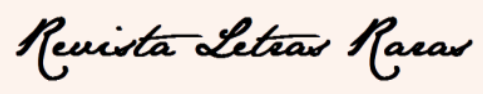

ISSN: $2317-2347$ - v. 8, n. 2 (2019)

Nessa evocação da tela de Klint, a citação remete à contradição de sua vontade de "agradar a todos" que ela tenta externar sendo perfeita em toda a sua aparência. Se na imagem que remete ao grito Anne não quer ouvir, colocando as mãos sobre as orelhas, nessa figura, além de falar, ela aceita os conselhos que a levam a ser como os outros desejam.

Klint, pintor simbolista austríaco e continuador do expressionismo, apresenta uma ornamentação elaborada e complexa, realizada a óleo e ouro sobre tela, pintura do período dourado de sua obra. "O dourado invade o fundo e é o elemento fundamental do vestido onde a ornamentação integra a iconografia habitual do pintor na fase dourada, espirais micênicas, olhar ao estilo egípcio, círculos, retângulos e xadrezes" (BRITO, 2016). ${ }^{19}$ Klint gostava de moda e retratava isso em seus quadros. Nessa obra,

[a] posição de Adele na composição é ambígua, pois tanto parece que está sentada como de pé. Ela se encontra luxuosamente vestida, como se fosse uma rainha, mas parece sufocada em meio a tanto ornamento e riqueza.[...] O ouro compõe o vestido da retratada e o fundo da composição (LUDIASBH, 2015). ${ }^{20}$

É importante notar que o autor da HQ vai buscar em uma pintura em ouro a imagem para essa passagem. Se retomarmos a frase de 30 de janeiro de 1943 do diário de Anne que foi suprimida na HQ, encontramos uma alusão ao ouro "preferiria o meiotermo de ouro, que não é tão dourado assim, e guardar para mim meus pensamentos" (FRANK; PRESSLER, 2018, p. 93, grifo nosso). Ainda que as palavras de Anne remetam a uma ideia abstrata, "o ponto certo entre dois extremos", o substantivo ouro é retomado na HQ sob forma de citação visual: a cor dourada ajuda a contrapor as duas Annes, os dois extremos. A posição de Adele, ambígua, também pode ser transferida para Anne que descreve sentimentos ambíguos em relação à sua vida e à sua família. Ao mesmo tempo que Anne quer se mostrar uma garota sem problemas, está sufocada por todos que a rodeiam.

As duas telas retomam com força as palavras de Anne e deslocam o olhar do leitor, receptor dessa citação visual; a mídia pintura lança e relança a dinâmica do

\footnotetext{
${ }^{19} \mathrm{http}$ ///estoriasdahistoria12.blogspot.com/2014/01/analise-da-obra-o-retrato-de-adele.html

${ }^{20} \mathrm{http} / / /$ virusdaarte.net//klimt-retrato-de-adele-bloch-bauer-i/

Todo o conteúdo da Revista Letras Raras está licenciado sob Creative Commons Atribuição 4.0 Internacional
} 


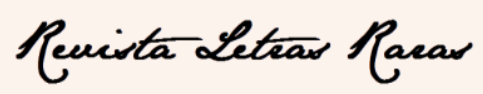

ISSN: $2317-2347$ - v. 8, n. 2 (2019)

sentido e do fenômeno dos sentimentos de Anne ampliando o campo de entendimento de seu sofrimento e suas contradições.

Compagnon (2016, p. 512) confere dois valores à citação, o "valor de significação ou de uso, quer dizer o sentido do propósito citado" e o "valor de repetição ou de menção ligado ao fato de citar". Segundo o autor, a "citação é mais carregada de sentido que o texto no qual se insere" e "essa sobrecarga de sentido mantém menos o propósito da citação por si mesmo que o fato de citar" (COMPAGNON, 2016, p. 512). O autor ainda acrescenta que "a citação é então um objeto linguístico curioso, porque ela é formulada por duas vozes, a de seu primeiro autor e a daquele que a retoma" (COMPAGNON, 1979, p. 512, tradução nossa). ${ }^{21}$

Nessa citação visual, a imagem vai construir outras imagens e um dos elementos para essa construção é a própria citação. Apesar de ser uma imagem repetida, ela é qualificada. Mais que uma retomada genérica, a citação cria uma relação de copresença entre imagens/textos/conteúdo e temas retomados. O sentido dessa citação não se reduz ao que é citado, ela não constitui uma prática que guarda o sentido; há valores significantes que se acrescentam; o texto citante acolhe o texto citado.

\section{Conclusão}

O diário de Anne Frank, em sua versão textual, tem atingido e emocionado diferentes públicos em diferentes épocas. Por sua força textual, ele é objeto possível de recriações das mais diversas. Esse artigo se interessou especificamente por sua transposição para a mídia HQ por acreditar que o trabalho de Folman e Polonsky oferece campo de estudo para fenômenos como a referência intermidial e, particularmente, a citação visual.

O artigo realizou, assim, a apresentação crítica de um exemplo concreto da ampliação de sentidos que deriva da combinação de sistemas semióticos, conforme postulado, teoricamente, por Clüver (2011) e Kristeva (1996). No processo, ofereceu

\footnotetext{
${ }^{21}$ Texto no original : «Une citation a deux valeurs, d'abord une « valeur de signification », ou d'usage, c'est-à-dire le sens du propos cité, mais aussi une «valeur de répétition », ou de mention liée au fait de citer, par exemple dans le cas d'un argument d'autorité. La citation est plus chargée de sens que le texte dans lequel s'insère ; cette surcharge de sens tient moins au propos de la citation en lui-même qu'au fait de le citer. La citation est donc un objet linguistique curieux, parce qu'elle est énoncée par deux voix, celle de son premier auteur et celle de celui que la reprend » (COMPAGNON, 2016, P. 512).

Todo o conteúdo da Revista Letras Raras está licenciado sob Creative Commons Atribuição 4.0 Internacional
} 


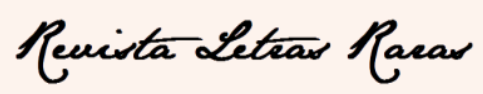

ISSN: $2317-2347$ - v. 8, n. 2 (2019)

também uma moldura teórica para a leitura dessa dinâmica de ampliação, enfatizando a importância do conceito de citação visual.

Através da possibilidade de usar a referência intermidial dentro do espaço da HQ transportando as imagens de duas pinturas conhecidas de um extenso público, os autores usam a citação visual para criar um diálogo tríptico: $\mathrm{HQ}$ /pintura/receptor. A citação visual retoma a tendência textual à transparência e se inscreve em uma estratégia de substituição. A montagem da citação feita pelos autores da HQ cria uma espécie de jogo que afeta e cria um novo sentido ao texto primeiro; há um desvio de contexto mas não de sentido da citação.

Segundo Compagnon,

[...] a citação tem o status de um critério de validade, de um controle de enunciação, de um dispositivo de regulação, às vezes até de autorregulação da repetição do já dito: "boa", ela qualifica; "ruim", ela desqualifica. Longe de ser um detalhe do livro, um traço periférico da leitura e da escritura, a citação representa um trunfo capital, um lugar estratégico e mesmo político, em toda prática da linguagem [...] (COMPAGNON, 1979, P. 12-13, tradução nossa). ${ }^{22}$

Anne termina seu diário dizendo que "tenta achar um modo de se transformar no que gostaria de ser e no que poderia ser... se não houvesse mais ninguém no mundo" (FRANK; PRESSLER, 2018, p. 345).

Folman e Polonsky, mais de sete décadas depois da composição do texto original, transformam Anne em várias Annes e ajudam a transportar e validar, através de recursos multimodais e intermidiais, de citações visuais carregadas de feixes de contradições, os sentimentos de uma jovem adolescente em pleno conflito mundial para o século XXI.

\section{REFERÊNCIAS}

\footnotetext{
22 Texto no original : « La citation a le statut d'un critère de validité, d'un contrôle d'énonciation, d'un dispositif de régulation, parfois d'autorégulation, de la répétition du déjà dit : «bonne », elle qualifie ; «mauvaise », elle disqualifie. Loin d'être un détail du livre, un trait périphérique de la lecture et de l'écriture, la citation représente un enjeu capital, un lieu stratégique et même politique, dans toute pratique du langage, quand elle assure sa validité, garantit sa recevabilité, ou au contraire les réfute » (COMPAGNON, 2016, p. 12-13).
}

Todo o conteúdo da Revista Letras Raras está licenciado sob Creative Commons Atribuição 4.0 Internacional 


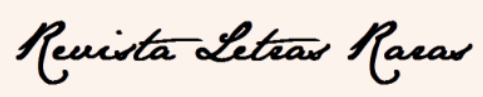

ISSN: 2317-2347 - v. 8, n. 2 (2019)

AUBERT, A. C. (organização). Monsieur Jabot. R. Töpffer. Tradução de Flavia Lago. São Paulo : SESI-SP Editora, 2017

BAETENS, J. Études Culturelles et Analyse Médiatique: autour du concept de remédiation. Recherches en communication, Louvain, $\mathrm{n}^{\mathbf{0}}$ 31, 2009. Disponível em: [http://sites.uclouvain.be/rec/index.php/rec/article/view/6351/6041]. Acesso em 15 set. 2018.

BARBIERI, D. As linguagens dos quadrinhos. Tradução de Thiago de Almeida Castor do Amaral. São Paulo: Editora Peirópolis, 2017

CAGNIN, A. L. Os quadrinhos - linguagem e semiótica. Um estudo abrangente da arte sequencial. São Paulo: Editora Criativo, 2014

CHAMBAT-HOUILLON, M-F. De l'audiovisuel vers le télévisuel: deux modèles de citation pour les émissions de télévision. Revue Ci-Dit, Nice, 2009, s/n. Disponível em : [http://revel.unice.fr/symposia/cidit/index.html?id=408]. Acesso em 10 set. 2018.

CLÜVER, C. Inter textos / Inter artes / Inter media. Revista Aletria, Belo Horizonte, 2006, v. 14. Disponível em:

[http://www.periodicos.letras.ufmg.br/index.php/aletria/article/view/1357/1454].

Acesso em: 14 set. 2018.

CLÜVER, C. Intermidialidade. Revista Pós (Revista do programa de pós-graduação em artes da EBA/UFMG), Belo Horizonte, 2011, v.1, n. 2. Disponível em: [ https://www.eba.ufmg.br/revistapos/index.php/pos/article/view/16/16]. Acesso em 10 ago. 2018.

COMPAGNON, A. O trabalho da citação. Tradução de Cleonice P. B. Mourão. Belo Horizonte: Editora UFMG, 1996

COMPAGNON, A. La seconde main ou le travail de la citation. France: Éditions du Seuil, 2016

EISNER, W. Quadrinhos e arte sequencial. Tradução de Luís Carlos Borges \& Alexandre Boide. São Paulo: Editora WMF Martins Fontes Ltda., 2015

FIORANI, E. Grammatica della comunicazione. Milão: Lupetti - Editori di Comunicazione, 2012

FOLMAN, A. \& POLONSKY, D. O diário de Anne Frank. Tradução de Raquel Zampil de Anne Frank : the graphic diary. Rio de Janeiro : Editora Record, 2017

GROENSTEEN, T. La bande dessinée mode d'emploi. France: Les Impressions Nouvelles, 2015

FRANK, O. H. \& PRESSLER, M. O diário de Anne Frank. Tradução de Alves Calado. Rio de Janeiro: Editora Record, 2018

MCCLOUD, S. Reinventando os quadrinhos. Tradução de Roger Maioli. São Paulo : M. Books do Brasil Ltda., 2006

MÉCHOULAN, E. Intermédialités: Le Temps des illusions perdues. Revue Intermédialités, Montreal, v. 1, $\mathrm{n}^{\mathrm{o}}$ 20, 2012. Disponível em: Todo o conteúdo da Revista Letras Raras está licenciado sob Creative Commons Atribuição 4.0 Internacional 


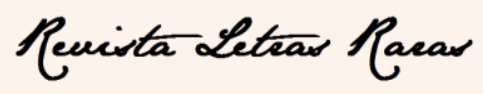

ISSN: 2317-2347 - v. 8, n. 2 (2019)

[https://www.erudit.org/fr/revues/im/2003-n1-im1814473/1005442ar/]. Acesso em: 18 set. 2018.

RAJEWSKY, I. Intermidialidade, Intertextualidade e "Remediação" - Uma perspectiva literária sobre a intermidialidade. In DINIZ, T. (organizadora). Intermidialidade $e$ estudos interartes. Tradução de Thaïs Flores Nogueira Diniz \& Eliana Lourenço de Lima Reis. Belo Horizonte: Editora UFMG, 2012, p.15-45

STRICKLAND, C. \& BOSWELL, J. Arte comentada. Tradução de Angela Lobo Andrade. São Paulo: Ediouro Publicações S.A., 1992

Data de recebimento: 02/04/2019

Data de aceite: 04/05/2019 